\title{
PENGARUH GOOD CORPORATE GOVERNANCE PADA KINERJA KEUANGAN DI PERUSAHAAN LQ45 YANG TERDAFTAR DI BURSA EFEK INDONESIA ( BEI )
}

\author{
Oleh: Meti Zuliyana ${ }^{1}$, Msy. Mikial, Muhammad Luthfi \\ (UNIVERSITAS TRIDINANTI PALEMBANG) \\ ${ }^{1)}$ metiyusuf@yahoo.com
}

\begin{abstract}
Abstrak
Penelitian ini bertujuan untuk mengetahui seberapa besar terjadinya pengaruh pada kinerja keuangan pada indikator - indikator good corporate governance pada perusahaan yang meliputi: komisaris independen, kepemilikan manajerial dan kepemilikan institusional adalah variabel yang diduga mempengaruhi kinerja keuangan pada perusahaan LQ45 di Bursa Efek Indonesia (BEI) atau Indonesia Stock Exchange (IDX). Penelitian ini memakai data sekunder yang diperoleh dari laporan keuangan tahunan yang diterbitkan oleh Bursa Efek Indonesia (BEI) atau Indonesia Stock Exchange (IDX) dengan menggunakan 12 sampel perusahaan dengan metode Purposive Sampling LQ45 pada periode 2011 sampai dengan 2015. Hasil penelitian dengan menggunakan alat uji regresi linier berganda menyatakan bahwa komisaris independen, kepemilikan manajerial dan kepemilikan institusional berpengaruh signifikan secara simultan (bersama - sama) terhadap kinerja keuangan yang diukur dengan ROA dengan tingkat signifikan (0,001), sedangkan secara parsial (individu) faktor fundamental perusahaan: komisaris independen, kepemilikan manajerial dan kepemilikan institusional tidak berpengaruh signifikan terhadap kinerja keuangan yang diukur dengan ROA. Sebaiknya, dalam penelitian ini dapat mencakup seluruh perusahaan LQ45 yang yang terdaftar di Bursa Efek Indonesia (BEI) dan lebih memperhatikan indikator-indikator good corporate governance yang lebih memiliki pengaruh terhadap kinerja keuangan (ROA). Disarankan untuk penelitian selanjutnya agar menambahkan indikatorindikator good corporate governance seperti dewan direksi dan komite audit diduga memiliki pengaruh signifikan terhadap kinerja keaungan (ROA).
\end{abstract}

Kata Kunci: Komisaris Independen, Kepemilikan Manajerial, Kepemilikan Institusional, Kinerja Keuangan (ROA) 


\title{
GOOD CORPORATE GOVERNANCE INFLUENCE TO FINANCIAL PERFORMANCE IN LQ45 COMPANY LISTED INDONESIA STOCK EXCHANGE ( IDX / BEI )
}

\begin{abstract}
Aim to research know how much to influence financial performance to good corporate governance indicator in company covers independent commissioner, managerial ownership and intitutional ownership to variable allegadly affect financial performance in LQ45 company Indonesia Stock Exchange (IDX) or BEI. Used secondary data to obatained from annual fiancial statement published Indonesia Stock Exchange (IDX) or BEI make use off twelve company Purposive Sampling LQ45 methode in the periode 2011 to 2015. The tool test research result to double linear regreation talked independent commissioner, managerial ownership and intitutional ownership significant influence simultaneously to financial performance as measured ROA sidnificant levels (0,001), partially for one person, the company fidamental factor: independent commissioner, managerial ownership and intitutional ownership not significant influence to financial performance as measured ROA, Financial Performance research should be includes all LQ45 company listed Indonesia Stock Exchange (IDX / BEI) and good corporate governance indicator more attention have influence to financial performance (ROA). The research recommended add good corporate govermance indicator board of directors and audit committe allege to have significant influence to financial performance (ROA)
\end{abstract}

Keyword : Independent Commissioner, Managerial Ownership and Intitutional Ownershi, Financial Performance (ROA)

\section{PENDAHULUAN}

Pengukuran

kinerja

keuangan adalah sebagai sarana atau indikator

dalam rangka memperbaiki kegiatan operasional perusahaan. Dengan perbaikan kinerja operasioanal diharapkan bahwa perusahaan dapat mengalami pertumbuhan keuangan yang lebih baik dan juga dapat bersaing dengan perusahaan lain lewat efisiensi dan efektivitas.

Kinerja keuangan perusahaan sendiri pada laporan keuangan dapat dilihat pada return on asset (ROA). ROA menunjukkan perusahaan dengan menggunakan seluruh aktiva yang dimiliki untuk menghasilkan laba setelah pajak. Rasio ini penting bagi pihak manajemen untuk mengevaluasi 
efektivitas dan efisiensi perusahaan. Semakin besar ROA, berarti semakin efisien penggunaan aktiva perusahaan atau dengan kata lain dengan jumlah aktiva yang sama bisa dihasilkan laba yang lebih besar, dan sebaliknya (Sudana, 2011:22).

Bursa Efek Indonesia (BEI) atau Indonesia Stock Exchange (IDX), adalah hasil penggabungan Bursa Efek Jakarta (BEJ) dengan Bursa Efek Surabaya (BES) yang merupakan sebuah pasar modal untuk menyediakan sistem atau sarana mempertemukan penawaran dan permintaan efek pihak-pihak lain dengan tujuan memperdagangkan efek di antara mereka. Untuk memberikan informasi yang lebih lengkap tentang perkembangan bursa kepada publik, BEI menyebarkan data pergerakan saham melalui indeks harga saham salah satunya di Indeks LQ45.

LQ45 merupakan suatu
forum yang didalamnya berisi
perusahaan - perusahaan yang
saham - sahamnya memiliki tingkat
likuiditas dan kapitalisasi pasar yang tinggi. Duduk di jajaran LQ45 merupakan suatu kehormatan bagi sebuah perusahaan karena itu berarti pelaku pasar modal sudah mengakui dan percaya bahwa tingkat likuiditas dan kapitalisasi pasar dari perusahaan ini baik. Sehingga sudah selayaknya perusahaan yang termasuk dalam LQ45 memiliki Good Corporate Governance yang baik pula.

Mengacu pada latar belakang penelitian di atas. Maka penulis melakukan telaah terhadap laporan keuangan yang diungkap oleh perusahaan LQ45 yang terdaftar di BEI 5 (lima) tahun terakhir terhitung dari tahun 20112015. Dari hasil telaah tersebut ditemukan fenomena bahwa terjadi penurunan nilai ROA pada perusahaan LQ45. Berikut, data ketercapaian Return on Asset (ROA) dari beberapa Perusahaan LQ45 dari tahun 2011 sampai dengan 2015. 
Grafik 1. Nilai Return on Asset Perusahaan LQ45 2011-2015

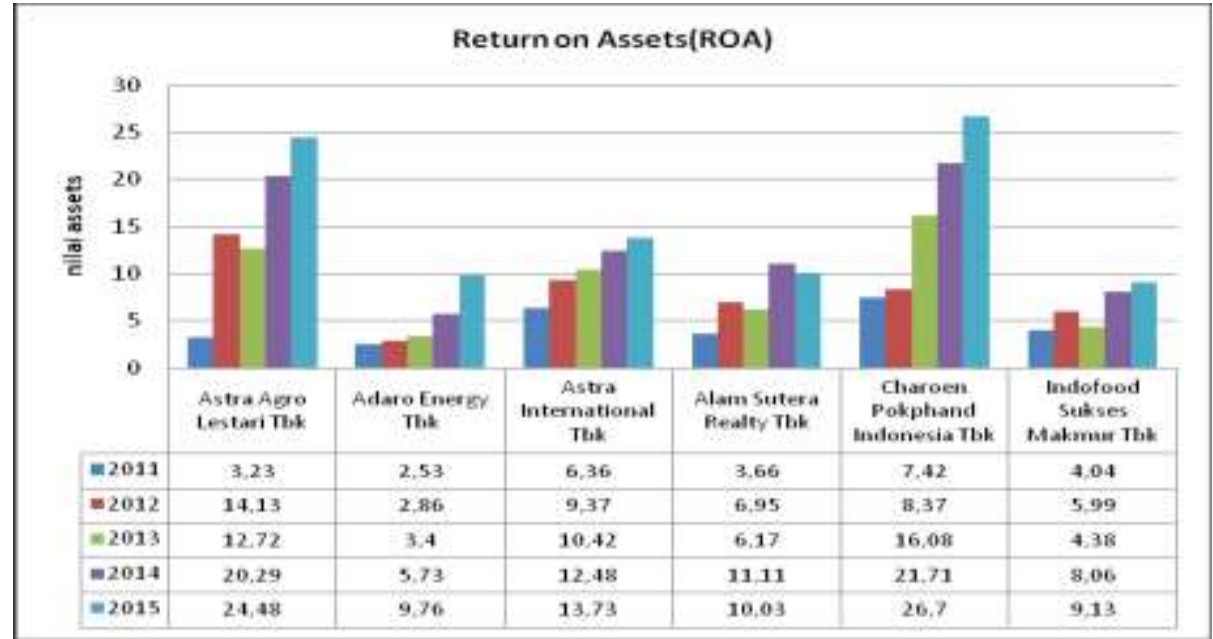

Sumber: BEI, data diolah

Pada tabel di atas beberapa perusahaan terlihat mengalami penurunan meskipun telah menerapkan Good Corporate Governance yang merupakan pedoman bagi manajer untuk mengelola perusahaan secara best practice. Hal ini dapat memperlihatkan kondisi kinerja keuangan mengalami peningkatan atau penurunan.

Melihat fenomena-fenomena yang terjadi seperti yang dikemukakan di atas, perlu dilakukan penelitian yang erat kaitannya dengan kinerja keuangan. Untuk itu saya selaku penulis memiliki ketertarikan untuk melakukan penelitian terhadap fenomena-fenomena yang telah diungkapkan untuk melihat adakah pengaruh antara Good Corporate Governance terhadap kinerja keuangan, sehingga penelitian ini mengambil judul PENGARUH GOOD CORPORATE GOVERNANCE TERHADAP KINERJA KEUANGAN PERUSAHAAN DI LQ45 YANG TERDAFTAR DI BURSA EFEK INDONESIA.

Berapa besar pengaruh Good Corporate Governance (Komisaris Independen, Kepemilikan Institusional, Kepemilikan Manajerial) secara simultan (bersama-sama) terhadap kinerja keuangan perusahaan LQ45 
yang terdaftar di Bursa Efek Indonesia?.

Berapa besar pengaruh Good Corporate Governance (Komisaris Independen, Kepemilikan Institusional, Kepemilikan Manajerial) secara parsial terhadap kinerja keuangan perusahaan LQ45 yang terdaftar di Bursa Efek Indonesia?.

Komite Audit Menurut PBI No.8/4/PBI/2006 tentang pelaksanaan good corporate governance, komite audit adalah pihak yang mendukung efektivitas pelaksanaan tugas dan tanggung jawab dewan komisaris. Peraturan tentang pembentukan dan tugas komite audit juga dikeluarkan oleh Badan Pengawas Pasar Modal (BAPEPAM) melalui Kep29/PM/2004 tentang pembentukan dan pedoman pelaksanaan kerja komite audit.

Menurut Arens at al (2010), menjelaskan pengertian komite audit adalah: "Audit committees is a selected number of members of a company's board of directors whose responsibilities include helping auditors remain independent of management. most audit committees are made up of three to five or sometimes as many as seven directors who are not a part of company management." Pernyataan tersebut menjelaskan bahwa umumnya komite audit itu terdiri dari tiga atau lima kadang tujuh orang yang bukan bagian dari manajemen perusahaan. Tujuan dibentuknya komite audit yaitu untuk menjadi penengah antara auditor dan manajemen perusahaan apabila terjadi perselisihan.

Berdasarkan definisi-definisi di atas maka dapat dijelaskan bahwa komite audit dibentuk oleh dewan komisaris yang bekerja sama dalam menjalankan tugas dan fungsi dewan komisaris.

Tugas dan tanggung jawab komite audit adalah memberikan pendapat kepada dewan komisaris terhadap laporan atau hal-hal yang disampaikan oleh dewan direksi, mengidentifikasi hal-hal yang berkaitan dengan tugas dewan komisaris. Komite audit melaksanakan fungsi pengawasan dan pengendalian dalam perusahaan. Melihat pentingnya peran komite 
audit dalam perusahaan maka ukuran komite audit dalam perusahaan perlu diperhatikan karena akan mempengaruhi kinerjanya. Ukuran komite audit menunjukkan jumlah komite audit yang dimiliki perusahaan baik. Dengan adanya komite aduit yang independen praktik manajemen laba dapat dieliminasi.

Tingkat Leverage, dapat diketahui bahwa leverage merupakan tingkat hutang dalam suatu perusahaan dan harus ditanggung oleh setiap perusahaan untuk meminimalkan laba pada setiap periodenya.

Menurut Martono dan Agus Harjito (2010:297) Leverage dalam pengertian bisnis merupakan mengacu pada penggunaan asset dan sumber dana oleh perusahaan dimana dalam penggunaan asset atau dana tersebut pada akhirnya akan dimaksudkan untuk meningkatkan keuntungan bagi pemegang saham.

Menurut Bambang Riyatno (2010:375) Leverage dapat didefinisikan sebagai pengguna aktiva atau dana dimana untuk penggunaan tersebut perusahaan harus menutupi biaya tetap atau membayar beban tetap.

Dapat disimpulkan bahwa leverage merupakan suatu tingkat kemampuan perusahaan dalam menggunakan aktiva atau dana yang mempunyai beban tetap (utang atau saham istimewa) dalam rangka mewujudkan tujuan perusahaan untuk memaksimalkan kekayaan pemilik perusahaan. Tingkat leverage merupakan alat untuk mengukur seberapa besar perusahaan tergantung pada kreditur dalam membiayai asset perusahaan. Perusahaan yang mempunyai tingkat leverage tinggi berarti sangat bergantung pada pinjaman luar untuk membiayai asetnya, sedangkan perusahaan yang mempunyai tingkat leverage lebih rendah lebih banyak membiayai asetnya dengan modal sendiri. Jadi dapat dikatakan bahwa tingkat leverage perusahaan menggambarkan risiko keuangan perusahaan.

Ukuran Perusahaan, karakteristik dari perusahaan yang paling penting adalah firm size (ukuran perusahaan). Perusahaan dengan skala yang lebih besar 
menikmati keuntungan yang lebih dibandingkan dengan perusahaan kecil dilihat dari skala dan jangkauan ekonomi yang dimiliki oleh perusahaan besar.

Menurut I Gusti Ayu Putu Sihta P (2011:66) Ukuran perusahaan dapat dikukur dengan perhitungan market capitalization, dimana merupakan nilai pasar total dari perusahaan yang dihitung dengan menggunakan harga pasar terbaru dikalikan jumlah saham.

Manajemen Laba, Earning Management atau manajemen laba merupakan suatu fenomena baru yang telah menambah wacana perkembangan teori akuntansi dan merupakan salah satu kajian yang menarik dalam riset akuntansi. Istilah manajemen laba muncul sebagai konsekuensi langsung dari upayaupaya manajer atau pembuat laporan keuangan untuk melakukan manajemen informasi akuntansi, khususnya laba, demi kepentingan pribadi dan atau perusahaan. Manajemen laba itu sendiri tidak dapat diartikan sebagai suatu upaya negatif yang merugikan karena tidak selamanya manajemen laba berorientasi pada manipulasi laba.

Menurut Assih dan Gundono (2000:37) mengartikan manajemen laba sebagai suatu proses yang dilakukan dengan sengaja dalam batasan General Accepted Accounting Principle (GAAP) untuk mengarah pada suatu tingkat yang diinginkan laba yang dilaporkan. Menurut Davidson, Stickney, dan Weil (Sulistyanto, 2008: 48) Earnings management is the process of taking deliberate steps within the constrains of generally accepted accounting principles to bring about desired level of reported earnings (Manajemen laba merupakan proses untuk mengambil langkah tertentu yang disengaja dalam batas-batas prinsip akuntansi berterima umum untuk menghasilkan tingkat yang diinginkan dari laba yang dilaporkan). Dari beberapa definisi di atas dapat disimpulkan bahwa manajemen laba mempunyai benang merah yang menghubungkan satu definisi dengan definisi yang lain yaitu menyepakati bahwa manajemen laba merupakan aktifitas 
manajerial untuk mempengaruhi dan mengintervensi laporan keuangan.

Dalam penelitian ini yang menjadi variable independennya atau variabel bebas adalah komite audit, leverage, dan ukuran perusahaan, sedangkan variabel dependen atau variabel terikatnya adalah manajemen laba.
Laba yang dilaporkan merupakan signal atas laba dimasa yang akan datang. Oleh karena itu pengguna laporan keuangan dapat membuat prediksi atas laba perusahaan untuk masa yang akan datang berdasarkan signal yang disediakan oleh manajemen melalui laba yang dilaporkan.

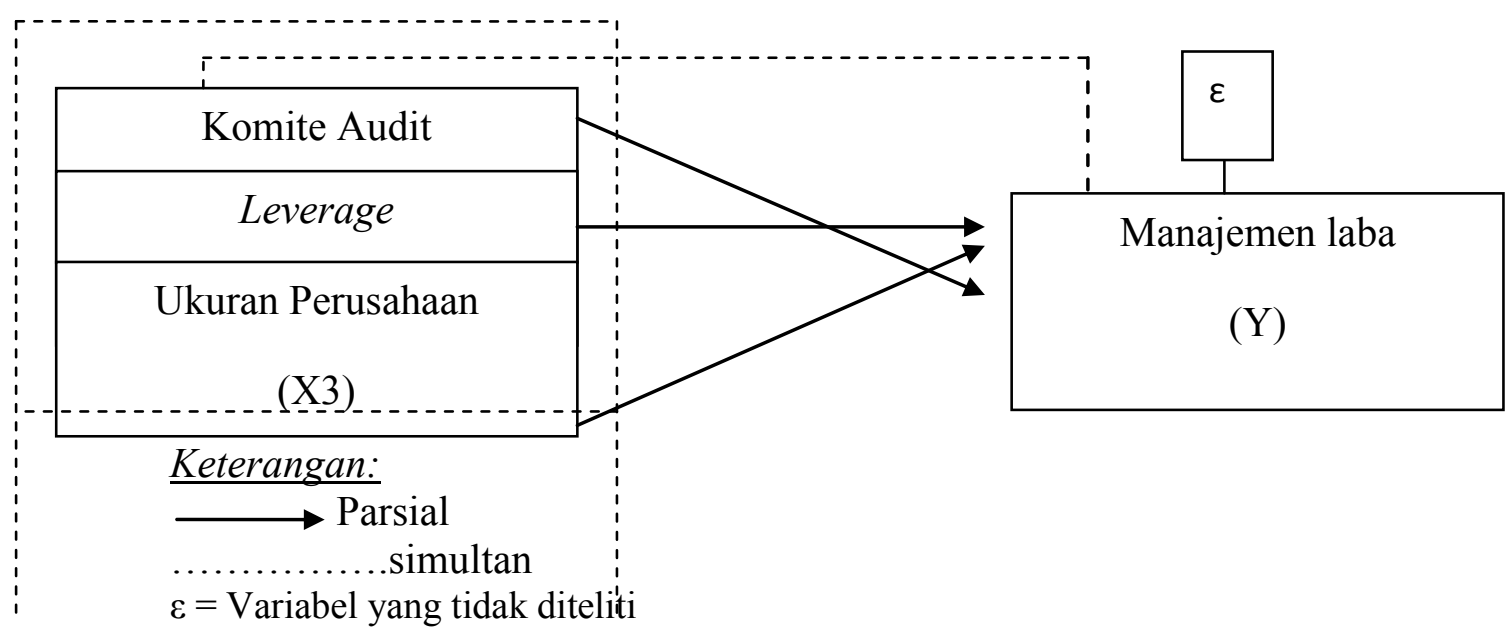

Hipotesis dalam penelitian ini, Komite audit, Leverage, dan Ukuran perusahaan berpengaruh terhadap manajemen laba pada perusahaan BUMN.

\section{PROSEDUR PENELITIAN}

Penelitian ini dilakukan pada perusahaan BUMN Persero yang terdaftar di Bursa Efek Indonesia pada website www.idx.co.id. Dalam penelitian ini penulis menggunakan data sekunder. Data sekunder yang digunakan dalam penelitian ini terdiri dari data keuangan perusahaan yang diperoleh dari laporan tahunan perusahaan BUMN Persero tahun 2013-2015 yang di unduh dari website resmi (http://www.idx.co.id). Data mengenai market capitalization diperoleh dari Indonesia Capital Market Directory (ICMD). Dalam 
penelitian ini, peneliti menggunakan data dokumentasi dalam melakukan penelitian ini adalah berupa laporan keuangan serta informasi-informasi yang didapat dari masing-masing Perusahaan BUMN Persero yang terdaftar di Bursa Efek Indonesia. Dalam penelitian ini yang menjadi populasi adalah 20 Perusahaan BUMN yang terdaftar di Bursa Efek Indonesia. Dari seluruh populasi yang ada sampel yang telah ditentukan terdiri atas 20 sampel perusahaan BUMN persero yang terdaftar di Bursa Efek Indonesia. Adapun kriteria yang ditetapkan untuk memperoleh sampel yaitu: Perusahaan BUMN Persero yang terdaftar di Bursa Efek Indonesia tahun 2013 sampai 2015. Sehingga penelitian ini memiliki total sampel yang diambil sebanyak 60 sampel. Variabel dalam penelitian ini adalah Variabel independen $(\mathrm{X}): \mathrm{X}_{1}($ Komite Audit), $\mathrm{X}_{2} \quad$ ( Tingkat Leverage), dan $\mathrm{X}_{3}$ ( Ukuran
Perusahaan ), Variabel dependen (Y): Y ( Manajemen Laba ). Uji statistik menggunakan Regresi Linier Berganda yang sebelumnya harus menggunakan uji asumsi klasik, apabila sudah memenuhi syarat maka dilanjutkan dengan Regresi Linier Berganda. Pengujian hipotesis Uji Koefisien Regresi Secara Parsial (Uji t) dan Uji Koefisien Regresi Secara Bersama-sama ( Uji F), Analisis Korelasi Ganda, dan Uji Koefisien Determinasi $\left(\mathrm{R}^{2}\right)$.

\section{HASIL PENELITIAN DAN PEMBAHASAN}

- Analisis Pengaruh Komite Audit, Leverage, dan Ukuran Perusahaan Secara Simultan Terhadap Manajemen Laba.

Uji $F$ atau koefisien regresi secara bersama-sama, yaitu untuk mengetahui variabel independen secara serentak terhadap variabel dependen, apakah pengaruh signifikan atau tidak. 
Tabel 1. Hasil Uji F (Simultan)

ANOVA $^{b}$

\begin{tabular}{|c|c|c|c|c|c|c|}
\hline \multicolumn{2}{|c|}{ Model } & $\begin{array}{l}\text { Sum of } \\
\text { Squares }\end{array}$ & Df & Mean Square & $\mathrm{F}$ & Sig. \\
\hline \multirow[t]{3}{*}{1} & Regression & 16.038 & 3 & 5.346 & 86.933 & $.000^{\mathrm{a}}$ \\
\hline & Residual & 1.660 & 27 & .061 & & \\
\hline & Total & 17.699 & 30 & & & \\
\hline
\end{tabular}

a. Predictors: (Constant), Ukuran Perusahaan, Komite Audit, Leverage

b. Dependent Variable: Manajemen Laba

Hasil penelitian ini bahwa terjadi pengaruh komite audit,

menunjukkan bahwa komite audit, leverage dan ukuran perusahaan dengan nilai pengujian hipotesis $\mathrm{F}$ hitung 192,860 > 2,776, sehingga $\mathrm{H}_{0}$ ditolak dan $\mathrm{H}_{\mathrm{a}}$ diterima, yang berarti bahwa variabel independen yang terdiri dari komite audit, leverage dan ukuran perusahaan secara simultan berpengaruh signifikan terhadap manajemen laba pada perusahaan BUMN Persero yang terdaftar di Bursa Efek Indonesia (BEI). Hasil penelitian ini sejalan dengan hasil penelitian yang dilakukan oleh I Gusti Ayu Putu Shita (2011) yang menunjukkan leverage, dan ukuran perusahaan terhadap manajemen laba di Bursa Efek Indonesia (BEI).

- Analisis Pengaruh Komite Audit, Leverage, dan Ukuran Perusahaan Secara Parsial Terhadap

Manajemen Laba.

Uji $\mathrm{t}$ atau koefisien regresi secara parsial, yaitu untuk mengetahui variabel independen yaitu komite audit, tingkat leverage, dan ukuran perusahaan apakah berpengaruh secara signifikan atau tidak terhadap variabel dependen ( Manajemen laba ). 
Tabel 2. Hasil Uji t (Parsial)

Coefficients $^{a}$

\begin{tabular}{|c|c|c|c|c|c|c|}
\hline \multirow{2}{*}{\multicolumn{2}{|c|}{ Model }} & \multicolumn{2}{|c|}{$\begin{array}{l}\text { Unstandardized } \\
\text { Coefficients }\end{array}$} & \multirow{2}{*}{$\begin{array}{c}\begin{array}{c}\text { Standardized } \\
\text { Coefficients }\end{array} \\
\text { Beta }\end{array}$} & \multirow[b]{2}{*}{$\mathrm{t}$} & \multirow[b]{2}{*}{ Sig. } \\
\hline & & B & Std. Error & & & \\
\hline 1 & (Constant) & -1.194 & .511 & & -2.337 & .027 \\
\hline & Komite Audit & .403 & .362 & .068 & 1.113 & .275 \\
\hline & Leverage & -.847 & .154 & -.983 & $|-5.490|$ & .000 \\
\hline & $\begin{array}{l}\text { Ukuran } \\
\text { Perusahaan }\end{array}$ & 1.766 & .174 & 1.839 & 10.132 & .000 \\
\hline
\end{tabular}

a. Dependent Variable: Manajemen Laba

Berdasarkan hasil uji $\mathrm{t}$ hasil ini bertentangan dengan (parsial) pada indikator komite audit penelitan yang dilakukan oleh I Gusti menunjukkan signifikansi sebesar Ayu Putu Shita (2011) yang 1,113 dimana angka signifikannya $>$ menunjukkan adanya pengaruh 0,05 maka sesuai dengan kriteria pengujian hipotesis yang telah ditetapkan sehingga $\mathrm{H}_{0}$ diterima dan $\mathrm{H}_{\mathrm{a}}$ ditolak yang berarti komite audit secara parsial tidak berpengaruh signifikan terhadap manajemen laba pada perusahaan BUMN Persero yang terdaftar di Bursa Efek Indonesia (BEI).

Hasil penelitian ini didukung oleh penelitian yang dilakukan oleh Siti Nayiroh (2013) dan Muhammad Ardiansyah (2013). Dimana hasil penelitian menunjukkan bahwa komite audit tidak berpengaruh terhadap manajemen laba. Namun positif dan signifikan terhadap manajemen laba di BEI.

Keberadaan komite audit dalam suatu perusahaan, yang menjadi aspek penilaian good corporate governance belum mampu menegakkan good corporate governance dalam kaitannya dengan praktik manajemen laba. Dalam pelaksanaan tugasnya, komite audit belum mampu memberikan kontribusi dalam kualitas pelaporan keuangan. Komite audit seharusnya meningkatkan integritas dan kredibilitas pelaporan keuangan melalui pengawasan atas proses 
pelaporan termasuk sistem kreditor, sehingga fleksibilitas pengendalian internal dan manajemen untuk melakukan penggunaan prinsip akuntansi manajemen laba semakin berkurang. berterima umum serta mengawasi Berdasarkan hasil uji $t$ proses audit secara keseluruhan.

Berdasarkan hasil uji $t$ (parsial) pada indikator ukuran perusahaan menunjukkan (parsial) pada indikator leverage menunjukkan signifikansi sebesar 5,490 dimana angka signifikannya < 0,05 maka sesuai dengan kriteria pengujian hipotesis yang telah ditetapkan yang berarti $\mathrm{H}_{\mathrm{o}}$ ditolak dan $\mathrm{H}_{\mathrm{a}}$ diterima yang berarti bahwa leverage berpengaruh negatif dan signifikan terhadap manajemen laba.

Hasil penelitian ini sejalan dengan penelitian yang dilakukan oleh Riko Perdana (2012) dan Paskah Ika Nugroho (2014). Dimana hasil penelitian menunjukkan bahwa leverage menunjukkan pengaruh negatif dan signifikan terhadap manajemen laba.

Dalam hal ini jika tingkat kewajiban yang tinggi maka pihak manajemen perusahaan menjadi lebih sulit dalam membuat prediksi jalannya perusahaan ke depan. Semakin besar utang yang dimiliki perusahaan maka semakin ketat pengawasan yang dilakukan oleh

signifikansi sebesar $10,132>0,05$ maka sesuai dengan kriteria pengujian hipotesis yang telah ditetapkan berarti $\mathrm{H}_{0}$ ditolak dan $\mathrm{H}_{\mathrm{a}}$ diterima, yang berarti bahwa ukuran perusahaan secara parsial berpengaruh signifikan terhadap manajemen laba.

Hasil penelitian ini didukung dengan hasil penelitian yang dilakukan oleh I Gusti Ayu Putu Shita (2011) yang menunjukkan bahwa terjadi pengaruh yang signifikan ukuran perusahaan terhadap manajemen laba.

Ukuran perusahaan dinilai dari market capitalization. Semakin besar ukuran perusahaan semakin mendapat sorotan dari masyarakat (pihak luar). Besarnya sorotan dari pihak luar terhadap perusahaan menyebabkan manajemen lebih berhati-hati dalam melaporkan kondisi perusahaan dan cenderung untuk menyampaikan informasi- 
informasi yang baik. Untuk itu manajemen perusahaan melakupkan manajemen laba. Semakin besar ukuran perusahaan semakin besar praktik manajemen laba dan sebaliknya. Perusahaan yang berukuran besar akan menanggung biaya politik yang besar karena itu perusahaan yang besar memiliki motivasi untuk melakukan manajemen laba dengan menurunkan laba guna menurunkan biaya politiknya.

\section{PENUTUP}

\section{Kesimpulan}

1. Secara Simultan (bersama-sama) Hasil uji F (simultan) pada tabel di atas dengan nilai pengujian hipotesis, F hitung sebesar 86,933 dan $\mathrm{F}$ tabel sebesar 2,96 pada nilai signifikan 0,000 sehingga $\mathrm{H}_{0}$ ditolak dan $\mathrm{H}_{\mathrm{a}}$ diterima, yang berarti bahwa variabel independen yang terdiri dari komite audit, leverage dan ukuran perusahaan secara simultan berpengaruh signifikan terhadap manajemen laba pada perusahaan BUMN Persero yang terdaftar di Bursa Efek Indonesia (BEI).
2. Secara parsial (individu)

Hasil uji t pada indikator komite audit menunjukkan signifikansi sebesar sebesar 1,113 dimana angka signifikannya $>0,05$ maka sesuai dengan kriteria pengujian hipotesis yang telah ditetapkan sehingga $\mathrm{H}_{0}$ diterima dan $\mathrm{H}_{\mathrm{a}}$ ditolak yang berarti komite audit secara parsial tidak berpengaruh signifikan terhadap manajemen laba pada perusahaan BUMN Persero yang terdaftar di Bursa Efek Indonesia (BEI). Hasil uji t pada indikator leverage menunjukkan signifikansi sebesar $-5,490$ dimana angka signifikannya $<0,05$ maka sesuai dengan kriteria pengujian hipotesis yang telah ditetapkan yang berarti $\mathrm{H}_{\mathrm{o}}$ ditolak dan $\mathrm{H}_{\mathrm{a}}$ diterima yang berarti bahwa leverage berpengaruh negatif dan signifikan terhadap manajemen laba. Hasil uji t pada indikator ukusran perusahaan menunjukkan signifikasi sebesar 10,132>0,05 maka sesuai dengan kriteria pengujian hipotesis yang telah ditetapkan berarti $\mathrm{H}_{0}$ ditolak dan 
$\mathrm{H}_{\mathrm{a}}$ diterima, yang berarti bahwa ukuran perusahaan secara parsial berpengaruh signifikan terhadap manajemen laba.

\section{Saran}

- Bagi peneliti selanjutnya, agar dapat menambah variabel lain selain komite audit, leverage dan ukuran perusahaan yang mempengaruhi manajemen laba, memperpanjang periode pengamatan lebih dari 3 tahun, menambah kategori perusahaan yang akan dijadikan sampel penelitian kedepannya, menambah variabel yang tidak terdapat pada penelitian ini, seperti: struktur kepemilikan, komisaris independen dan pertumbuhan penjualan.

\section{DAFTAR PUSTAKA}

Ardiansyah, Muhammad. 2014. Pengaruh Corporate Governance, Leverage dan Profitabilitas Terhadap Manajemen Laba pada Perusahaan Manufaktur Sektor Industri Barang Konsumsi yang Terdaftar di BEI Periode 2009-2013. Fakultas Ekonomi Universitas Maritim Raja Ali Haji. Riau.
Arens, Alvin A, dkk. 2010. Auditing and Assurance Service: An Integrated Approach. Pearson Education: Prentice Hall Inc.

Arikunto, S. 2010. Prosedur Penelitian: Suatu Pendekatan Praktik (Edisi Revisi). Rineka Cipta:Jakarta.

Aryani, Dwi Septa. 2011. Manajemen Laba Pada Perusahaan Manufaktur di Bursa Efek Indonesia. Politeknik Palcomtech Palembang. Jurnal Ekonomi dan Informasi Akuntansi (Jenius).

Assih dan Gundono. 2000. Hubungan Tindakan Perataan Laba Dengan Reaksi Pasar Atas Pengumuman Informasi Laba Perusahaan. Jurnal Riset. Indonesia

Bursa Efek Indonesia. 2013. http://www.idx.co.id. "Laporan Keuangan Tahunan" BUMN Persero tahun 2013-2015.

Fahmi, Irham. 2015. Pengantar Manajemen Keuangan. Cetakan Ke empat. Alfabeta: Bandung.

Ghozali, Imam dan Chariri Anis. 2003. Teori Akuntansi. Edisi Keiga. Badan Penerbit Universitas Diponegoro: Semarang.

Harahap, Sofyan Safri. 2011. Teori Akuntansi. Edisi Revisi 2011. Cetakan Kesebelas. Rajawali Pers: Jakarta.

Ikatan Akuntan Indonesia. 2015. Pernyataan Standar Akuntansi Keuangan. Salemba Empat: Jakarta.

Indriantoro, Nur. 2002. Metodelogi Penelitian Bisnis untuk Akuntansi dan Manajemen. 
Cetakan Ke Dua. BPFEYogakarta: Yogyakarta.

Kasmir. 2014. Analisis Laporan Keuangan. Edisi Pertama, Cetakan Kedua, PT Rajagrafindo Persada: Jakarta. Nayiroh, Siti. 2011. Analisis Faktorfaktor yang Mempengaruhi Praktik Manajemen Laba. Fakultas Ekonomi dan Bisnis. Universitas Dian Nuswantoro: Semarang.

Nugroho, Paskah Ika. 2014. Pengaruh Mekanisme Corporate Governance, Ukuran Perusahaan dan Leverage Terhadap Manajemen Laba dan Kinerja Keuangan. Fakultas Ekonomika dan Bisnis. Universitas Kristen Satya Wacana. Salatiga

Rangkuti, Nur Aminah. 2015. Analisa Faktor-faktor yang Berpengaruh Terhadap Manajemen Laba pada Perusahaan Automotif yang Terdaftar di Bursa Efek Indonesia. Fakultas Ekonomi Universitas Sumatera Utara: Medan.

Perdana, Riko. 2012. Pengaruh Firm Size, Leverage, Good Corporate Governance, dan Profitabilitas Terhadap Earning Management. Fakultas Ekonomi dan Bisnis Universitas Diponegoro. Semarang.

Permatasari, Ika. 2005. Manajemen Laba dan Status Keterlambatan Perusahaan Dalam Menyampaikan Laporan Keuangan Tahunan. Jurnal Akuntansi dan Keuangan Indonesia.
Pristine, Shally. 2011. Demi Gaya Hidup, Konsumen Berhemat. Republika.

Sariva. 2016. Pengaruh Tingkat Leverage dan Pertumbuhan Penjualan Terhadap Pertumbuhan Laba pada Perusahaan Industri Makanan dan Minuman yang Terdaftar di IDX. Fakultas Ekonomi Universitas Tridinanti: Palembang.

Sanusi, Anwar. 2011. Metodologi Penelitian Bisnis. Salemba Empat: Jakarta.

Shita, I Gusti. 2011. Analisa Faktorfaktor yang Berpengaruh Terhadap Manajemen Laba (Studi pada Perusahaan Sektor Perbankan yang Terdaftar di BEI tahun 2006-2008).

Fakultas Ekonomi Universitas Diponegoro: Semarang.

Sujarweni, Wiratna V. 2015. Metode Penelitian Bisnis dan Ekonomi. Edisi Pertama. Pustaka Baru Press: Yogyakarta.

Sugiyono. 2016. Metode Penelitian Kuantitatif, Kualitatif, dan $R \& D$. Alfabeta: Bandung.

Sulistyanto, Sri. 2008. Manajemen Laba Teori dan Model Empiris. Grasindo: Jakarta.

Suwardjono. 2010. Teori Akuntansi. Edisi Ketiga. Edisi Ketiga. Cetakan Keempat. BPFE: Yogyakarta.

Vhika, Meiriasari. 2016. Pengaruh Corporate Governance, Kepemilikan Keluarga, Kepemilikan Institusional dan Ukuran Perusahaan terhadap Biaya Utang. Fakultas Ekonomi Universitas Sriwijaya: Palembang. 
http://www.2007.

Suaramerdeka.com/harian/070

6/02/eko02.htm 